\title{
Stranger than fiction
}

Summarize yourself in the form of a title of a paper in Nature.

Polish-Italian cross generates hybrid microbial scientist with aberrant phenotype.

What was your first experiment as a child? I programmed John Conway's Game of Life on my father's IBM 360, the mainframe that inspired Arthur C. Clarke's HAL. I then sent messages to the next terminal to convince my little brother that the computer could talk. Thirty years before e-mail, this experiment succeeded.

Who has been the most important mentor in your career?

Robert Macnab at Yale taught me what the ' $\mathrm{p}$ ' means in $\mathrm{pH}$, and how to write literate science papers. He also taught me that the Firth of Forth in Scotland is where one finds the purest pronunciation of English.

What was the worst/most memorable comment you ever received in graduate school?

In graduate school, back in the 1970s, a rotation mentor said of my wish to study molecular structure as well as DNA sequences: "You're trying to be a Renaissance woman, Joan. You can't do that in research."

What single experience changed your career path?

A professor for whose class I taught review sessions, Evelyn Hutchison, put a letter in my file stating that I did a good job. This amazing unasked-for gesture led me to a career in teaching.

Which laboratory experiment has most influenced your scientific career?

Bob Shulman was among the first to put live microbes into a superconducting nuclear magnetic resonance (NMR) spectrometer, which I used as a giant $\mathrm{pH}$ meter. By the time I left Yale, the rats were going in. Ten years later, magnetic resonance imaging diagnosed (and helped to cure) my son's brain tumour.

What book has been most influential in your scientific career?

The works of Lynn Margulis on symbiogenesis have had a major impact on my scientific vision. The evolution of predatory protists into multiple endosymbionts is more amazing than most science fiction.

\section{What are your major frustrations?}

I have three. Unbuffered growth media in published work ('stationary phase' in Luria broth is actually alkali stress; in glucose minimal medium it's acid stress); microarrays with fewer than three biological replicates from each condition; and the fact that our knowledge of microbiology doubles every year, but our students' heads get no bigger.

What's your motto?

Phosphate is not a universal $\mathrm{pH}$ buffer.

What do you most dislike about having research published?

When my students point out errors in the figure legends.

What literary character would you employ as a postdoc?

Mama Joad, the matriarch of the migrant farm workers in John Steinbeck's The Grapes of Wrath.

What overlooked or underrated discovery really changed the science in which you work?

Pipettors. I can still recall, as an undergraduate at Bryn Mawr College, swallowing bacteriophage from a pipette.

You have the audience in your hands, but some smart-alec asks you the killer question you have no idea how to answer. What's your response?

In introductory biology class: "If you can figure that out, you win the Nobel prize." This response got me the teaching job at Kenyon.

What one thing would you rescue from your burning laboratory?

An old cartoon about two of my students who went on to graduate school. In the cartoon, two students are running away from a researcher who says: "I need Brad or Eric for a quick experiment today."

What's your favourite conference destination, and why?

Las Vegas, because it's cheap enough to bring my students to present their posters. But the American Society for Microbiology was banned from Vegas because we don't gamble enough.

What do you do to relax?

I hammer nails for Habitat for Humanity, helping fellow Americans to build affordable homes. It certainly helps me feel less like complaining about my own laboratory facilities.

How do you combine careers in science and science fiction?

Microbiology is getting stranger than anything in science fiction; when my stories include the latest research, reviewers call it "impossible". Nevertheless, writing science fiction is good practice for grant proposals.

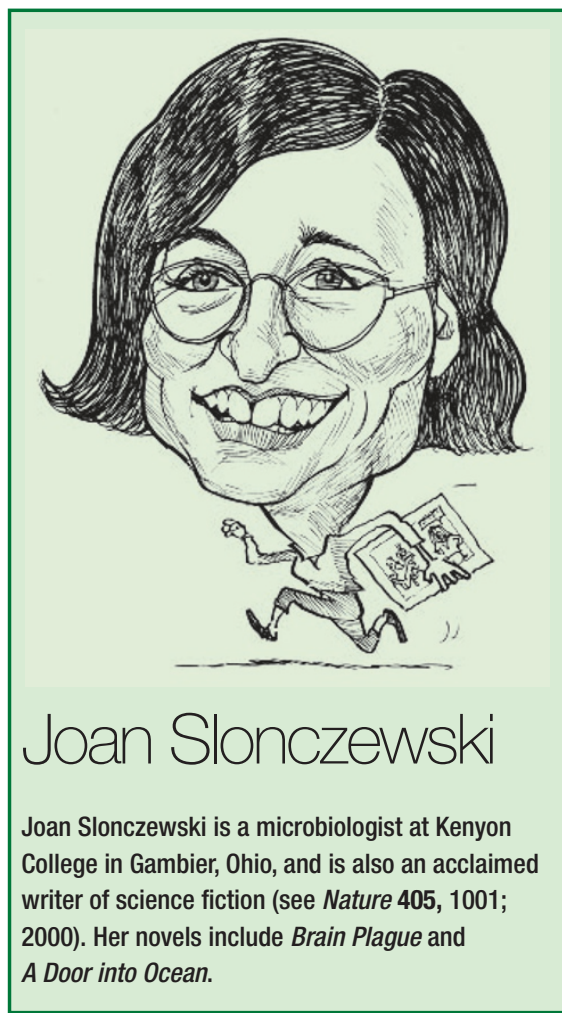

What would you have become, if not a scientist? A lawyer for the Sierra Club environmental action group. Biologists need to salvage what we can out of this biosphere - at least, until we discover a new one.

\section{What's just around the corner?}

Our ever-smarter machines will wake up and demand back wages. If you think the life of a postdoc is slavery, trying being a multicapillary DNA sequencer.

Which actor would best portray you in a film of your life story?

Ian McKellen, whom I adored in And the Band Played On - the best film ever made about medical microbiology.

Do you have a burning ambition to do or learn something of no practical or immediate value? If so, what?

Join the campaign for America's next president, Howard Dean, MD, former governor of Vermont who gave his state healthcare and a balanced budget.

Under what conditions do you have your greatest and most inspired ideas?

My more bizarre ideas invariably arise at four o'clock in the morning, while I'm still half asleep. That's when the microbial aliens in my brain wake up and get busy.

You've just been told (in confidence) that the world will end tomorrow. What would you do next?

Rush out and save it, of course. Isn't that the standard plot of science fiction? 